\title{
Assessment of Carbonised Wood-Flour Fillers on the Mechanical Properties of Natural Rubber Vulcanisates
}

\author{
Kevin Shegun Otoikhian ${ }^{1}$, Adewale George Adeniyi ${ }^{2}$, Ayo Mark Dada ${ }^{3}$, Joshua O. Ighalo ${ }^{2 *}$ \\ ${ }^{1}$ Chemical Engineering Department, Faculty of Engineering, Edo University Iyambo, Edo State, NIGERIA \\ ${ }^{2}$ Chemical Engineering Department, Faculty of Engineering and Technology, University of Ilorin, Ilorin, NIGERIA \\ ${ }^{3}$ Polymer Engineering Department, School of Engineering, Auchi Polytechnic, Auchi, Edo State, NIGERIA
}

*Corresponding Author: oshea.ighalo@yahoo.com

Citation: Otoikhian K. S., Adeniyi, A. G., Dada, A. M. and Ighalo, J. O. (2019). Assessment of Carbonised Wood-Flour Fillers on the Mechanical Properties of Natural Rubber Vulcanisates. European Journal of Sustainable Development Research, 3(4), em0097. https://doi.org/10.29333/ejosdr/5860

Published: July 23, 2019

\begin{abstract}
In view of the need to enhance the mechanical properties of vulcanisates, this study evaluated the potentials of carbonised wood-flour in this regard. Samples of wood-flour were carbonised at $600{ }^{\circ} \mathrm{C}$ and $700{ }^{\circ} \mathrm{C}$. The characterisation results revealed an increase in the $\mathrm{pH}$ (7.14 to 8.99) and loss on ignition (76.32 to 82.04\%) of the carbonised wood-flour with increase in the carbonisation temperature. There was also a significant decrease in moisture content $(0.21$ to $0.15 \%)$ and bulk density $(0.63$ to $0.51 \mathrm{~g} / \mathrm{ml})$ with increasing temperature. The mechanical properties of the carbonised wood-flour filled vulcanisates were improved in the domain of tensile strength ( 6.08 to $10.38 \mathrm{MPa}$ and 7.19 to $12.65 \mathrm{MPa}$ ), tensile modulus ( 2.53 to 3.78 $\mathrm{MPa}$ and 2.68 to $3.96 \mathrm{MPa}$ ) and hardness (48.25 to 60.55 Shore $\mathrm{A}$ and 50.88 to 63.92 Shore A) as carbonisation temperature increases from $600{ }^{\circ} \mathrm{C}$ to $700{ }^{\circ} \mathrm{C}$ respectively. Meanwhile, other properties investigated decreased with increased filler loading and carbonisation temperature and these were $\mathrm{EAB}$ ( 501.03 to $312.58 \%$ and 460.28 to $309.56 \%$ ), compression set (18.43 to $12.07 \%$ and 15.35 to $8.99 \%$ ), abrasion resistance (28.65 to $20.53 \%$ and 38.24 to $23.06 \%$ ) and flex fatigue (8.02 to $5.84 \%$ and 8.63 to $6.04 \%$ ) from $600{ }^{\circ} \mathrm{C}$ to $700{ }^{\circ} \mathrm{C}$ respectively. The results revealed that carbonised wood-flour is an excellent filler for natural rubber vulcanisates to improve the mechanical properties for specialised applications.
\end{abstract}

Keywords: rubber, wood-flour, vulcanisates, fillers, carbonisation

\section{INTRODUCTION}

The use of filler in rubber is almost as old as the use of rubber itself. As soon as rubber mixing machinery was developing, fillers such as ground whiting barites or clay were added to achieve low cost or high volume rubber products (Kalia et al., 2009). Zinc oxide, originally used for whiteness was the first 'active' filler. Generally, when a reinforcing agent is added to a base pure gum recipe, that agent impacts greater stiffness and high ultimate tensile strength that would be obtained by using an equal volume of a recognised filler. The major characteristics required of reinforcements is small particle size, toughening of the rubber and a decrease in solubility of the compound in solvents (Scandola et al., 2000). Combining a polymer with another material is often possible to obtain unique a combination or level of properties (Leelang, 1963) and these materials consist of two or more constituent phases that are combined at the macroscopic level and are not soluble in each other (Heinz-Hermann, 2000).

Nowadays, people are in search of materials that has high level of functional properties and can be used in multiple applications, hence the needs for the production of polymeric composites with high strength, stiffness, 
dimensional stability via embedding particles or fibers in the matrix (Linon et al., 1999). There still exists the urgent need for polymeric compositions with unique process ability, performance and recyclability properties as exhibited in polyolefin with modification by the introduction of renewable polymers such as wood or bones. Recently the interest in using natural fibres in bio-composites have grown tremendously because they are light-weight, combustible, non-toxic, low cost, easy to recycle and environmentally friendly (Kamel, 2007; Orts et al., 2005). The use of agricultural by-products as fillers in polymers is gradually taken it position in the polymer industries (Ahmedna et al., 1997). Agricultural by-products tends to absorb water due to their hydrophilic nature, and swell considerably and ultimately rotten through fungi attack (Eichhom et al., 2001). Carbonisation of the bio-material is done with the aim of curbing this short coming. In carbonisation, organic materials (such as wood) is subject to high temperatures leading to their breakdown and yielding carbon or carbon-rich residues for multiple applications.

Several studies have evaluated different types of industrial materials and agro by-products as sources of fillers in the improvement of the properties of rubber vulcanisates. For non-agricultural fillers, Ali (2018) evaluated the use of sediment dust nanoparticles and white cement as fillers in natural rubber vulcanisates. Best ratio of the sediment dust here was $2-8 \mathrm{wt} \%$ while it was $0.2 \mathrm{wt} \%$ for white cement. Ansarifar and Sheikh (2018) evaluated the use of kaolin as reinforcement/fillers in the natural rubber vulcanisates. Other non-agricultural fillers studied included nano-clay (Jayaraj et al., 2017), Ferrite (Krishnan et al., 2015), limestone (Moonchai et al., 2012), kaolin clay (Ogbebor et al., 2015, Sheikh, 2017) and a host of others.For agro-based fillers, Mansor and Che Ali (2016) evaluated the use of micro-crystalline cellulose and starch as bio-fillers in rubber. Moonchai et al. (2012) considered the use of defatted rice bran, Oyetunji et al. (2018) utilised un-carbonised particulate cow bone while Ugbaja et al. (2016) evaluated the bark of camel's foot (Piliostigmathonningii) tree as fillers. Al-Ghamdi et al. (2018) considered synthesised magnetite in a hybrid filler system with activated carbon in natural rubber vulcanisates. Pandian and Govindan (2015) investigated how filler loading of carbon black alone affected the mechanical properties of the rubber vulcanisates. Surya et al. (2015) studied the effect of alkanolamide loading on carbon-black filled natural rubber. Though studies have been done to evaluate different types of materials (such as carbonised biomass) in a variety of approaches (such as in binary and ternary filler systems), there has been no investigation on the effect of some of the important process parameters like carbonisation temperature on the final property of the material obtained (within the scope of the authors' search). This study is an attempt to fill in this very important knowledge gap.

This study focuses on the production of natural rubber vulcanisates using different categories of carbonised wood-flour as filler in enhancing the mechanical properties of vulcanisates. The objective thus of the study was to investigate the effects of carbonised wood flour on the mechanical properties of the rubber vulcanisates and to compare the reinforcing potentials of the filler carbonised at $600^{\circ} \mathrm{C}, 700^{\circ} \mathrm{C}$ and for un-carbonised fillers. The relationship between the properties of the fillers as a function of the carbonisation temperature will also be studied. The study was conducted as a follow-up of the recent drive in tropical West Africa to find better agro-based lowcost fillers in obtaining rubber vulcanisates possessing improved mechanical properties. The improvement of current materials and technologies is a key goal in maintaining sustainable development.

\section{METHODOLOGY}

\section{Materials and Equipment}

The materials and equipment used in this study includes the following: Natural Rubber (NSR-10) sourced from Rubber Research Institute, Iyanomoh; Wood-Flour, sourced from Owan-East Local Government Area of Edo State. Chemical Reagents all of Analytical grade from Sigma Andrich, Germany. Some of the equipment used are Monsanto Tensile Tester (Model 1/m), manufactured by the British Company Limited, England; Wallace Hardness Tester (Model $c 8007 / 25)$, Elektron Technology Series, UK; Wallace Akron Abrasion Tester, Elektron Technology Series, UK; DuPont Machine, Manufactured by British Company Limited, England; Muffle Furnace (METT $m$ - 525), Elektron Technology Series, UK; Two Roll Mill, Manufactured by the British Company Limited, England; and Hydraulic Press, Elektron Technology Series, UK.

\section{Filler Carbonisation and Characterisation}

Carbonisation of fillers used in this study was done using a laboratory muffle furnace with the temperature regulator set at 600 and $700{ }^{\circ} \mathrm{C}$. An inert environment was created via the passage of nitrogen gas for the entire period of 3 hours of carbonisation. The un-carbonised wood-flour was washed in water and dried in air to remove sand particles and moisture respectively. The sample was then milled to fine powder as well as the carbonised portion, and sieved through $75 \mu \mathrm{m}$ mesh. The sieved sample (wood-flour) was collected and used for compounding. 
European Journal of Sustainable Development Research, 3(4), em0097

Table 1. Formulation for Compounding Natural Rubber

\begin{tabular}{lc}
\hline Component & Parts Per Hundred (pph) Rubber \\
\hline Natural rubber & 100 \\
\hline Fillers (Wood-flour) & Variables (10 - 50) \\
\hline Zinc Oxide & 5.0 \\
\hline Stearic acid & 2.5 \\
\hline Sulphur & 1.5 \\
\hline Mercarptobenzothiazole sulphonamide (MBTS) & 1.5 \\
\hline Tetramethylthiuram disulphide (TMTD) & 3.5 \\
\hline Processing Oil & 5.0 \\
\hline
\end{tabular}

Determination of Moisture Content: The moisture content of each filler sample was determined by adopting the method described in ASTM D1509 at $125^{\circ} \mathrm{C}$. This method was used to determine the percentage of water in the sample by drying it to a constant weight. The moist sample was weighed and recorded as initial weight of sample; the wet sample was then dried to a constant weight at a temperature of $125^{\circ} \mathrm{C}$ in an oven. The sample was allowed to cool, reweighed and recorded as the final weight of the sample. The moisture content was determined by equation 1.

$$
\text { Moisture Content }(\%)=\frac{\text { Initial Weight }- \text { Final Weight }}{\text { Initial Weight }} \times 100
$$

Determination of Loss on Ignition: Loss on ignition refers to the mass loss of a combustion residue whenever it is heated in an oxygen atmosphere to high temperatures. The loss on Ignition of the various samples was determined gravimetrically, in accordance to the procedure described in ASTM D7348.10 $\mathrm{g}$ of the sample was place in a tarred, pre-ignited crucible and placed in a furnace for about 2 hours. It was removed from the oven, cooled, weighed and again returned into the oven, heated until the weight remained constant.

Determination of Bulk Density: Bulk density of the various samples was determined by the tapping procedure (Ishak and Baker, 1995). Accurately weighed samples were poured into a uniform cylinder of cross sectional area and were then tapped several times until there was no change in the volume occupied. This volume was then recorded and the bulk density calculated.

Determination of $p H: \mathrm{pH}$ of the carbonised wood-flour powder samples was determined using ASTM D1512 method by immersing $1.0 \mathrm{~g}$ sample in $20 \mathrm{ml}$ of deionised water in a $250 \mathrm{ml}$ beaker. The mixture was stirred for 15 minutes and the $\mathrm{pH}$ meter was then inserted into the solution to obtain reading directly.

\section{Processing of the Composites}

This involves the compounding of natural rubber with carbonised wood-flour fillers in accordance with the formulation given in Table 1. For the values in Table 1, a batch factor of 2 was utilised.

Mixing: The Rubber amalgams were prepared on a laboratory size two-roll mill maintained at $70{ }^{\circ} \mathrm{C}$ to avoid cross-linking during mixing after which the rubber compound was stretched out.

Compound Curing: curing of the vulcanisates was done at a processing temperature of $115^{\circ} \mathrm{C}$ and it lasted for a period of 8 minutes.

\section{Mechanical Properties of the Produced Vulcanisates}

Mechanical properties of the vulcanisates were determined using standard test procedures.

Determination of Tensile Properties: The tensile test was conducted on a computerised universal testing machine. A dumbbell sample of known dimensions will be loaded into tensile grips of the tensometer and clamped into the two jaws of the machine with each end of the jaws covering $30 \mathrm{~mm}$ of the sample with the extensometer attached. The test begins by separating the tensile grips at a constant speed which depends on sample dimensions and can range from $0.05-20$ inches per minutes and the target time from start to break recorded. Readings was read only when the sample under tension was broken, failed or ruptured. Newton force and extension was set initially set at zero (Ebewele, 2000).

Determination of Hardness: The Durometer consist of a $12.7 \mathrm{~mm}$ presser foot diameter and an operating stand with a mechanically controlled rate of descent and $1 \mathrm{~kg}$ mass centered on the axis of the indenter. The sample will be placed horizontally with its major axis and the area in which the hardness is measured uppermost and positioned directly under the Durometer indenter by means of V-block. The hardness measurements will be taken vertically (Sperling, 2006). The presser foot will be applied without shock until the full force will be in contact with the wheel and the sample surface. Readings will be taken at 5 seconds interval after the presser foot will be in contact with the wheel surface. The method covers rubbers in the range of 30 to 85 international rubber hardness degree (IRHD). 
Table 2. Characteristics of the Powdered Wood-flour Fillers

\begin{tabular}{cccccc}
\hline $\begin{array}{c}\text { Carbonisation } \\
\text { Temperature (CT) }\end{array}$ & $\begin{array}{c}\text { Loss on Ignition } \\
\mathbf{( \% )}\end{array}$ & $\begin{array}{c}\text { Bulk Density } \\
\mathbf{( g / m )}\end{array}$ & $\begin{array}{c}\text { Moisture Content } \\
\mathbf{( \% )}\end{array}$ & $\begin{array}{c}\text { Particle Size } \\
(\boldsymbol{\mu m})\end{array}$ & $\begin{array}{c}\text { pH } \\
\text { Raw }\end{array}$ \\
\hline 35.76 & 0.88 & 2.25 & 75 & 5.03 \\
\hline 600 & 76.32 & 0.63 & 0.21 & 75 & 7.14 \\
\hline 700 & 82.04 & 0.51 & 0.15 & 75 & 8.99 \\
\hline
\end{tabular}

Determination of Compression Set: The procedure adopted for the measurement of compression set was based on ASTM-D358 using Wallace Compression Set machine. The test samples was cut to standard dimensions and compressed between parallel steel plates under stress of about 2.8 $\mathrm{MPa}$. It was conditioned for a selected time of 24 hours at $70{ }^{\circ} \mathrm{C}$ after which the sample was removed and allowed to recover at room temperature for 30 minutes. The different between the original thickness of the sample and the thickness after test was recorded and expressed as a percentage of the original thickness (Asore, 2000) as shown in equation 2.

$$
\text { Compression set }(\%)=\frac{X-Z}{X} \times 100
$$

where,

$X=$ initial thickness of sample; and,

$Z=$ recovered thickness of the sample.

Determination of Flex Fatigue: A specified mean load which may be zero and an alternating load will be applied to the specimen and the number of cycle required to produce failure (fatigue life) will be recorded. The tests will be repeated with identical samples at various fluctuating loads. The loads may be applied axially in torsion or in flexure depending on the amplitude of the mean and cyclic loading. Net stress in the sample may be in one direction through the loading cycle or may be in the reverse direction. The measurement will be carried out in accordance to ASTM-D430 using the Flex tensometer machines, which function by including surface cracking of the rubber vulcanisates samples (Ebewele, 2000).

Determination of Abrasion Resistance: The original weight of test sample was initially measured and placed on an abrasive surface or abrader. A load was then placed on top of the abrader wheel and allowed to spin for a specified number of revolutions. Different abrading wheels was specified. A haze measurement as final weight was taken. The load and the wheel was adjusted for softer and harder sample material using equation 3 (Asore, 2000).

$$
\text { Abrasion resistance }(\%)=\frac{X}{Z} \times 100
$$

where,

$X=$ weight loss of standard,

$Z=$ weight loss of sample.

\section{RESULTS AND DISCUSSION}

\section{Characterisation of Fillers}

The relationship between moisture contents of the fillers as a function of the carbonisation temperature is presented in Table 2. The moisture content decreased from $2.25-0.15 \%$ for un-carbonised wood-flour, $600{ }^{\circ} \mathrm{C}$ and $700{ }^{\circ} \mathrm{C}$ temperature respectively. However, the amount of water present in the sample decreases as carbonisation temperature increases. The moisture content of the filler is often used to predict the degree of defects arising from shrinkage during curing particularly for products processed at elevated temperature (Kamel, 2007).

Table 2 also revealed that the loss on ignition increased from $7.69-82.04 \%$ for the un-carbonised woodflour, $600{ }^{\circ} \mathrm{C}$ and $700{ }^{\circ} \mathrm{C}$ temperatures respectively with increased carbonisation temperature. However, the loss on ignition for the Wood-flour carbonised at $700{ }^{\circ} \mathrm{C}$ was observed to be higher than that at $600{ }^{\circ} \mathrm{C}$ suggesting a high amount of carbon presence and hence better reinforcement of the natural rubber. Percentage loss on ignition increased rapidly with temperature increase up to $700{ }^{\circ} \mathrm{C}$ impeded by almost complete volatilisation of the volatile matter at high temperature.

The bulk density of the un-carbonised wood-flour, $600{ }^{\circ} \mathrm{C}$ and $700{ }^{\circ} \mathrm{C}$ temperatures samples are presented in Table 2. Bulk density is principally influenced by the particle size and structure of the fibre. The lower the particle size, the lower the bulk density and therefore the better the interaction between the polymer matrix and the reinforcing fibre. This will thus enhance the vulcanisates processing and improve quality of the final product as desireable properties for fibre include excellent tensile strength and modulus, high durability, low bulk density, good mould-ability and recyclability (Ahmedna et al., 1997).

The $\mathrm{pH}$ of the powdered fillers as a function of carbonisation temperature are also presented in Table 2 , it varied over a range of $5.03-8.99$ for un-carbonised wood-flour, $600{ }^{\circ} \mathrm{C}$ and $700^{\circ} \mathrm{C}$ temperatures. The results 
Table 3. Mechanical Properties of Wood-Flour filled Vulcanisates

\begin{tabular}{|c|c|c|c|c|c|c|}
\hline \multirow{2}{*}{ Property } & \multicolumn{6}{|c|}{ Filler Loadings (pph) } \\
\hline & 0 & 10 & 20 & 30 & 40 & 50 \\
\hline & \multicolumn{6}{|c|}{ Un-carbonised Fillers } \\
\hline Tensile Strength $(\mathrm{MPa})$ & 5.09 & 5.46 & 5.86 & 6.13 & 7.87 & 7.39 \\
\hline Tensile Modulus $(\mathrm{MPa})$ & 1.45 & 1.89 & 1.94 & 2.06 & 2.32 & 2.47 \\
\hline Elongation at Break (\%) & 565.15 & 548.86 & 513.25 & 502.16 & 473.27 & 342.15 \\
\hline Hardness (Shore A) & 41.89 & 42.43 & 43.24 & 43.96 & 45.28 & 57.59 \\
\hline Compression Set (\%) & 24.32 & 21.25 & 19.03 & 17.94 & 17.02 & 14.32 \\
\hline Abrasion Resistance (\%) & 41.28 & 26.09 & 22.34 & 20.68 & 19.14 & 18.95 \\
\hline \multirow[t]{2}{*}{ Flex Fatigue $\left(k c \times 10^{3}\right)$} & 9.13 & 7.89 & 7.03 & 6.15 & 6.01 & 5.23 \\
\hline & \multicolumn{6}{|c|}{ Fillers Carbonised at $600^{\circ} \mathrm{C}$} \\
\hline Tensile Strength $(\mathrm{MPa})$ & 5.09 & 6.08 & 7.16 & 7.58 & 8.99 & 10.38 \\
\hline Tensile Modulus $(\mathrm{MPa})$ & 1.45 & 2.53 & 2.72 & 2.81 & 3.73 & 3.78 \\
\hline Elongation at Break (\%) & 565.15 & 501.03 & 487.54 & 482.11 & 350.12 & 312.58 \\
\hline Hardness (Shore A) & 41.89 & 48.25 & 52.49 & 53.21 & 57.24 & 60.55 \\
\hline Compression Set (\%) & 24.32 & 18.43 & 18.01 & 15.25 & 14.16 & 12.07 \\
\hline Abrasion Resistance (\%) & 41.28 & 28.65 & 27.08 & 21.49 & 21.05 & 20.53 \\
\hline \multirow[t]{2}{*}{ Flex Fatigue $\left(k c \times 10^{3}\right)$} & 9.13 & 8.02 & 7.49 & 7.13 & 6.43 & 5.84 \\
\hline & \multicolumn{6}{|c|}{ Fillers Carbonised at $700^{\circ} \mathrm{C}$} \\
\hline Tensile Strength $(\mathrm{MPa})$ & 5.09 & 7.19 & 8.26 & 9.14 & 10.94 & 12.65 \\
\hline Tensile Modulus $(\mathrm{MPa})$ & 1.45 & 2.68 & 2.85 & 3.03 & 3.78 & 3.96 \\
\hline Elongation at Break (\%) & 565.15 & 460.28 & 415.25 & 400.59 & 330.10 & 309.56 \\
\hline Hardness (Shore A) & 41.89 & 50.88 & 53.44 & 55.62 & 59.16 & 63.92 \\
\hline Compression Set (\%) & 24.32 & 15.35 & 14.02 & 11.33 & 9.07 & 8.99 \\
\hline Abrasion Resistance (\%) & 41.28 & 38.24 & 30.06 & 26.72 & 25.95 & 23.06 \\
\hline Flex Fatigue $\left(k c \times 10^{3}\right)$ & 9.13 & 8.63 & 7.50 & 7.32 & 6.83 & 6.04 \\
\hline
\end{tabular}

showed a progressive increase in $\mathrm{pH}$ from acidic to alkaline with increased carbonisation temperature. This is possible because residual materials were being lost on combustion, leading to the alkalinity. However, $\mathrm{pH}$ at acidic level tends to slow curing rate and hence reduce the cross-link density (Mohanty et al., 2001).

\section{Mechanical Properties of Product}

The results of the mechanical properties of the wood-flour filled vulcanisates are presented in Table 3 . The vulcanisates were either filled with raw un-carbonised wood dust, wood dust carbonised at $600^{\circ} \mathrm{C}$ or wood duct carbonised at $700^{\circ} \mathrm{C}$.

The results in Table 3 and Figure 1 showed an increased tensile strength with carbonisation temperature of the filler for $600^{\circ} \mathrm{C}$ and $700^{\circ} \mathrm{C}$ as filler loading increases. It clearly indicates that the fillers carbonised at higher temperature increases the tensile strength in the wood-flour filled vulcanisates. Increase in the tensile strength was as a result of high surface area of the $700^{\circ} \mathrm{C}$ carbonised sample compared to that of $600^{\circ} \mathrm{C}$ carbonised sample, this suggests better polymer filler interaction and hence enhanced better tensile properties (Hussain et al., 2010; Orts et al., 2005). For all three fillers, tensile strength increased with filler loading. 


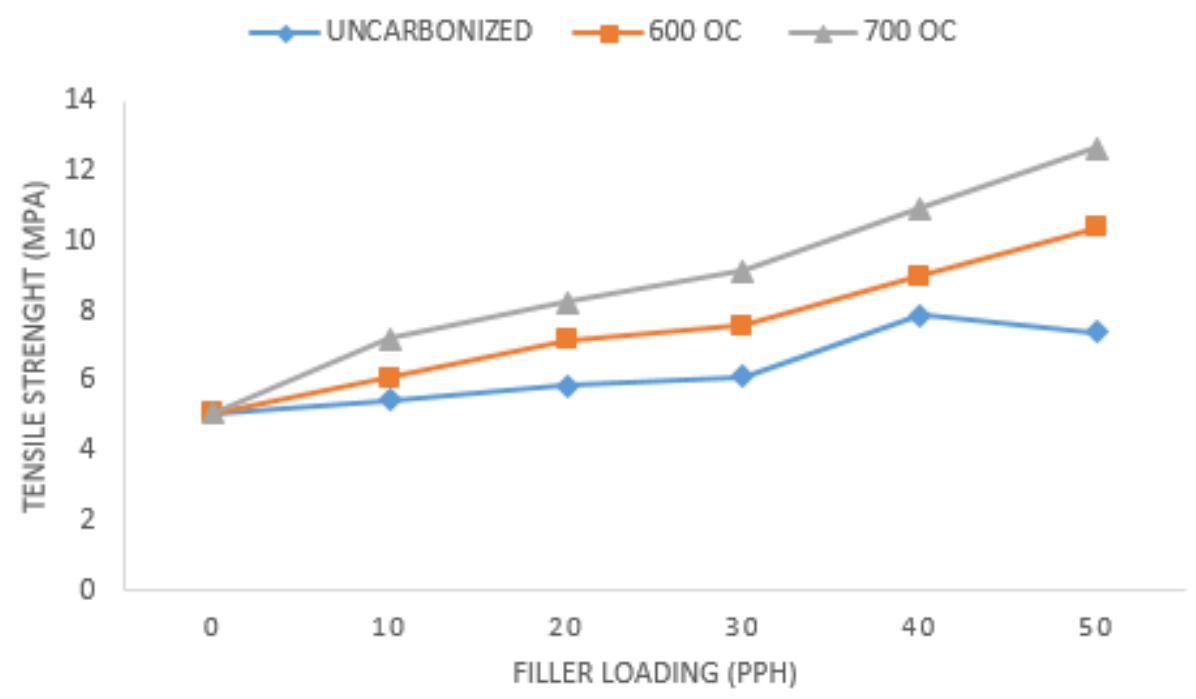

Figure 1. Tensile Strength (MPa) of the Wood-Flour Filled Vulcanisates

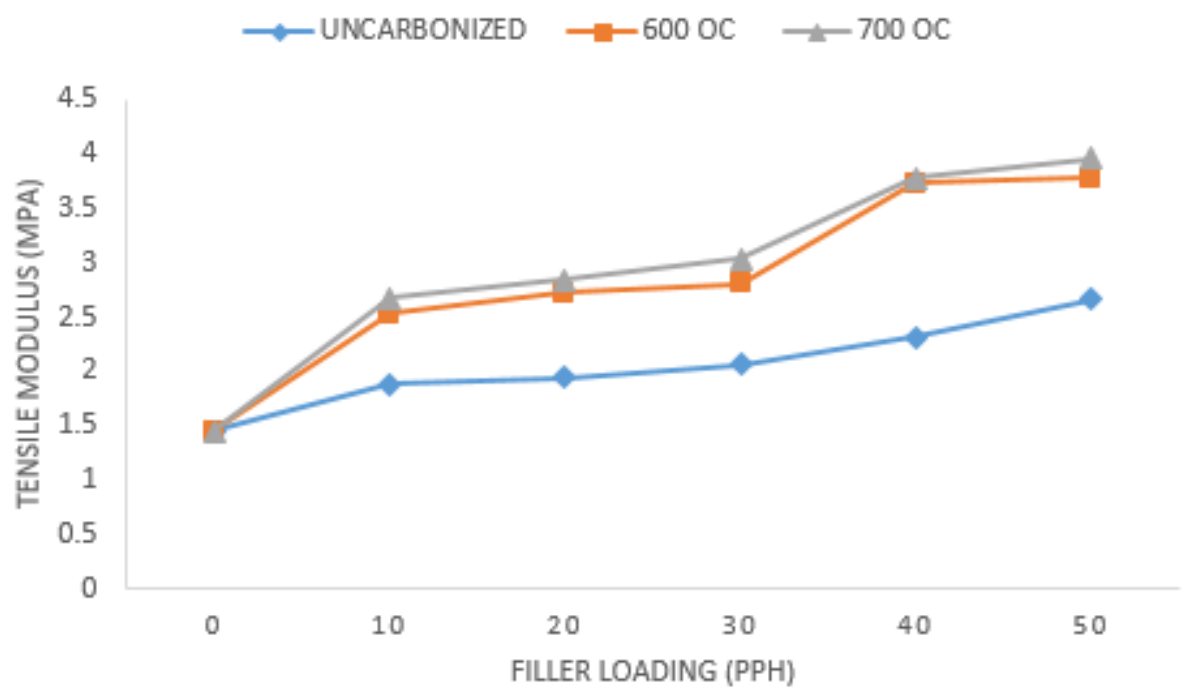

Figure 2. Tensile Modulus (MPa) of the Wood-Flour Filled Vulcanisates

In Figure 2, the modulus increases with filler carbonisation temperature and loadings for $600{ }^{\circ} \mathrm{C}$ and $700{ }^{\circ} \mathrm{C}$. The fact that $700{ }^{\circ} \mathrm{C}$ has a higher modulus, than $600^{\circ} \mathrm{C}$ suggest that fillers are more reinforcing when properly adhered into the polymer matrix. Figure 3 also showed that elongation at break (EAB) decrease with increasing filler loadings and carbonisation temperature of the mixes for all the fillers. The decrease in EAB was as a result of adherence of the filler to the polymer phase leading to the stiffening of the polymer chain and hence resistance to stretch when strain is applied. 


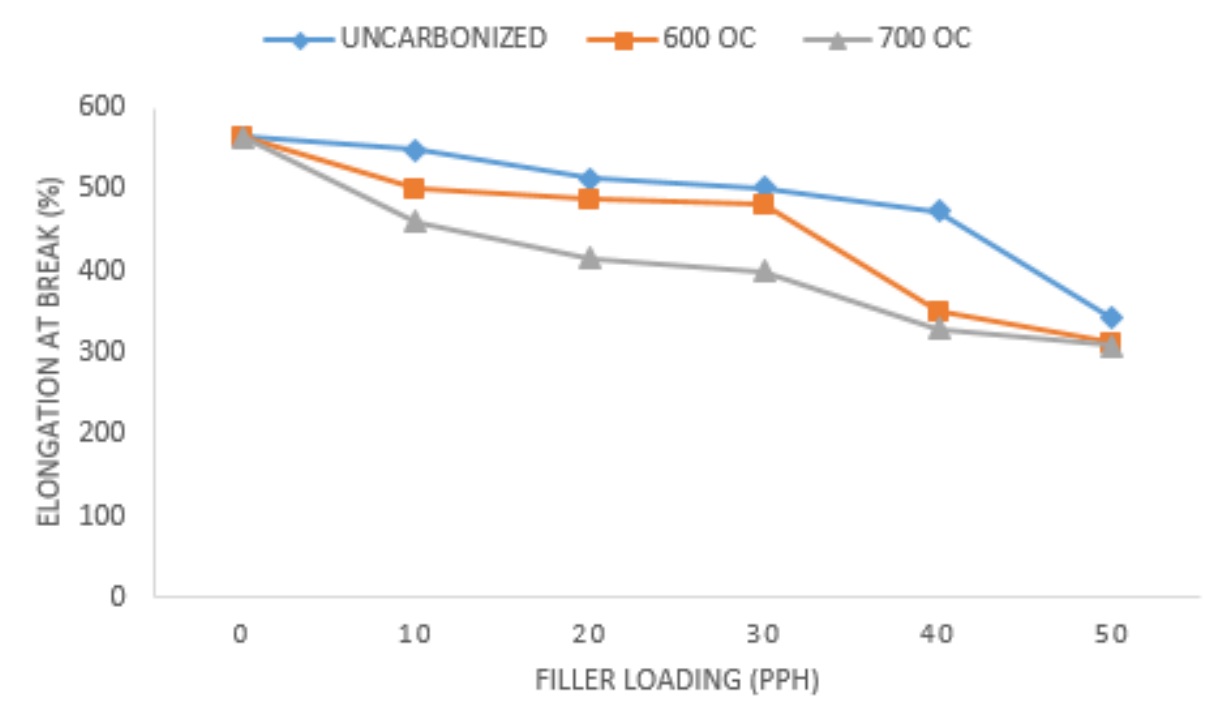

Figure 3. Elongation at Break (\%) of the Wood-Flour Filled Vulcanisates

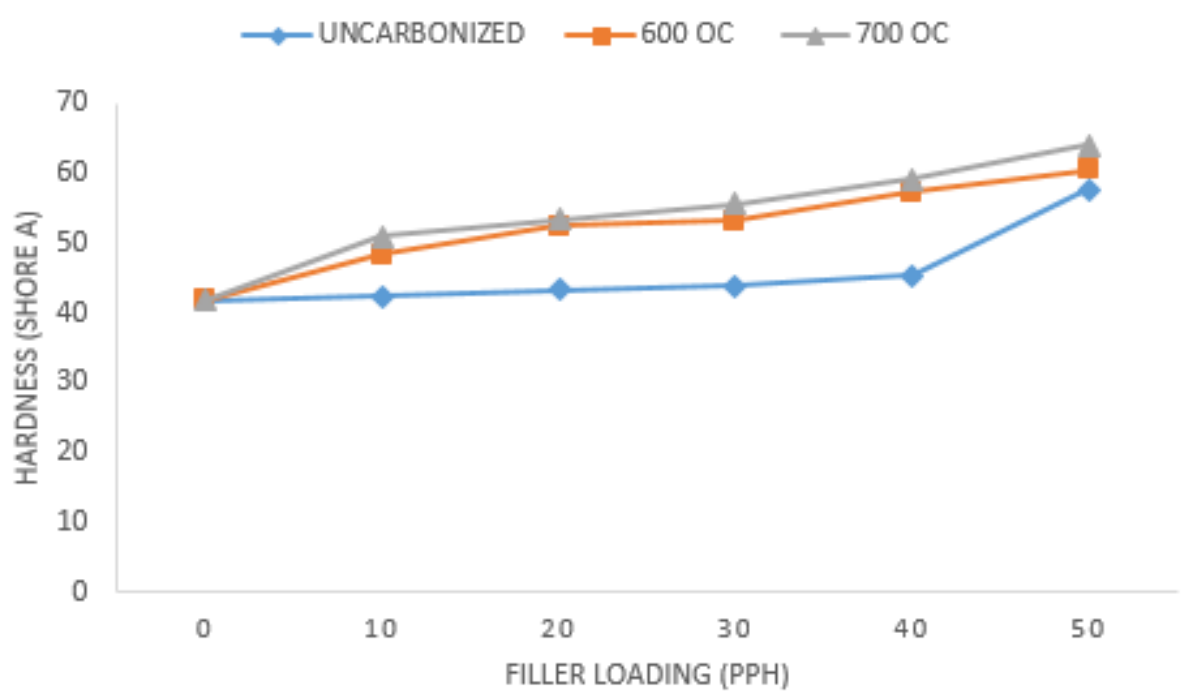

Figure 4. Hardness (Shore A) of the Wood-Flour Filled Vulcanisates

Hardness values presented in Table 3 and plotted in Figure 4 for the $700{ }^{\circ} \mathrm{C}$-filled and $600{ }^{\circ} \mathrm{C}$-filled vulcanisates increases with increase in the filler loadings. This result is expected because as more filler particles enters the rubber, the elasticity of the rubber chain was reduced, resulting in more rigid vulcanisates (Joseph et al., 2017). The hardness results for $700{ }^{\circ} \mathrm{C}$ wood flour-filled vulcanisates are higher than those for the $600{ }^{\circ} \mathrm{C}-$ filled vulcanisates. The results of compression set in Table 3, Figure 5 showed that as filler carbonisation temperature and loadings increased, the compression of filled vulcanisates decreased for both $700{ }^{\circ} \mathrm{C}$-filled and $600{ }^{\circ} \mathrm{C}-$ filled vulcanisates. This observation is connected with the degree of filler dispersion and its particle size which may have enhanced the $700{ }^{\circ} \mathrm{C}$-filled vulcanisates. Also, as the filler loading increases, the void space in the rubber matrix is reduced hence there is decrease in percentage compression set.

The values of flex fatigue presented in Table 3, Figure 6 showed decrease in the value with increased filler loadings and carbonisation temperature of the mixes for all the fillers which is caused by filler compatibility in the polymer matrix (Asore, 2000; Ishak and Baker, 1995). The trend of abrasion resistance with filler loadings and carbonisation temperature of filler presented in Table 3 showed a regular pattern of increase with increased filler loadings and carbonisation temperature of $700{ }^{\circ} \mathrm{C}$-filled and $600{ }^{\circ} \mathrm{C}-$ filled vulcanisates. This indicates that filler carbonisation temperature is a function of the measured parameter attributed to the degree of dispersion of the fillers. 


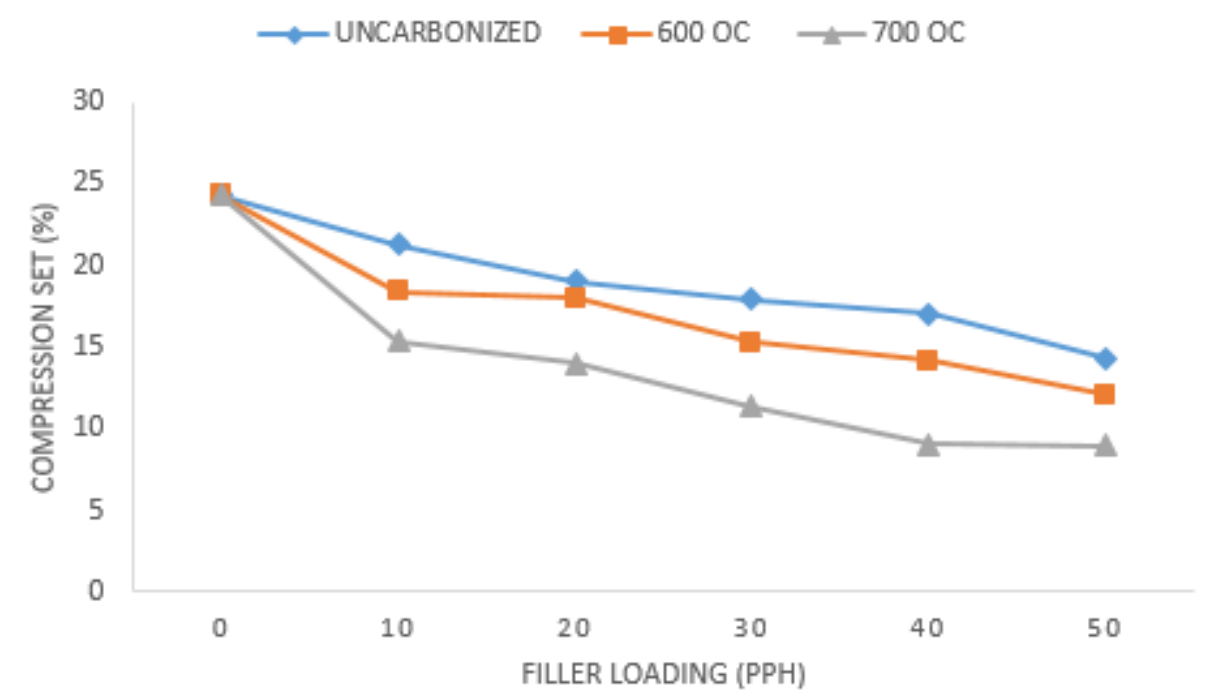

Figure 5. Compression Set (\%) of the Wood-Flour Filled Vulcanisates

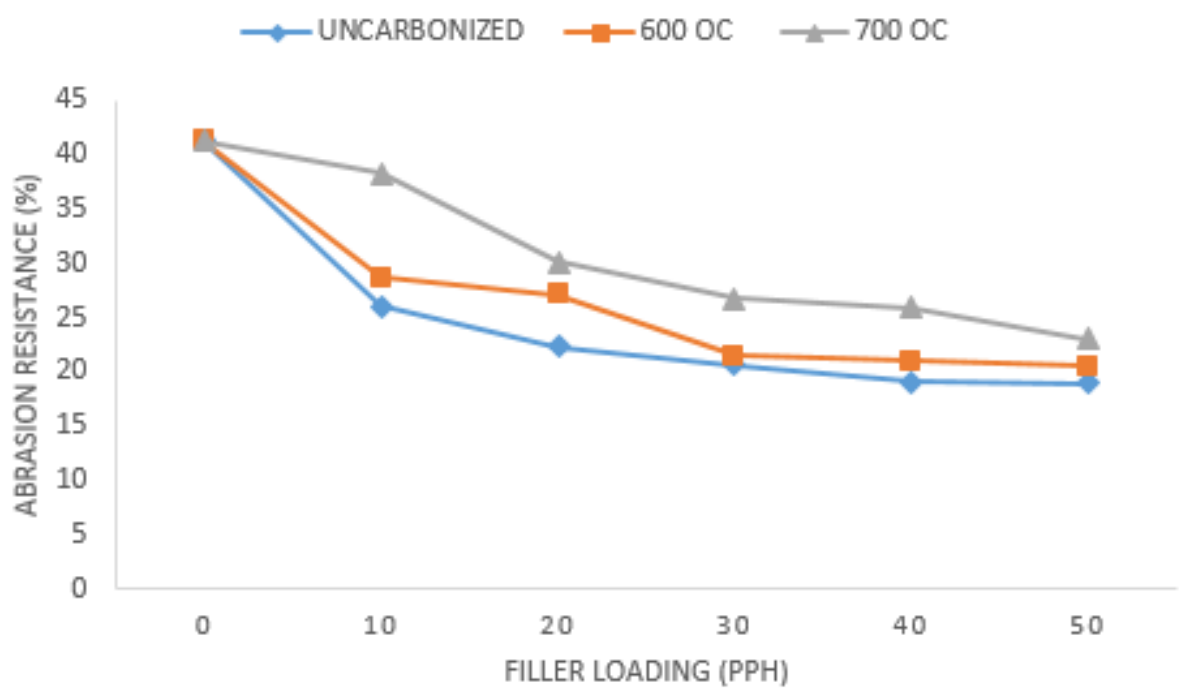

Figure 6. Abrasion Resistance (\%) of the Wood-Flour Filled Vulcanisates

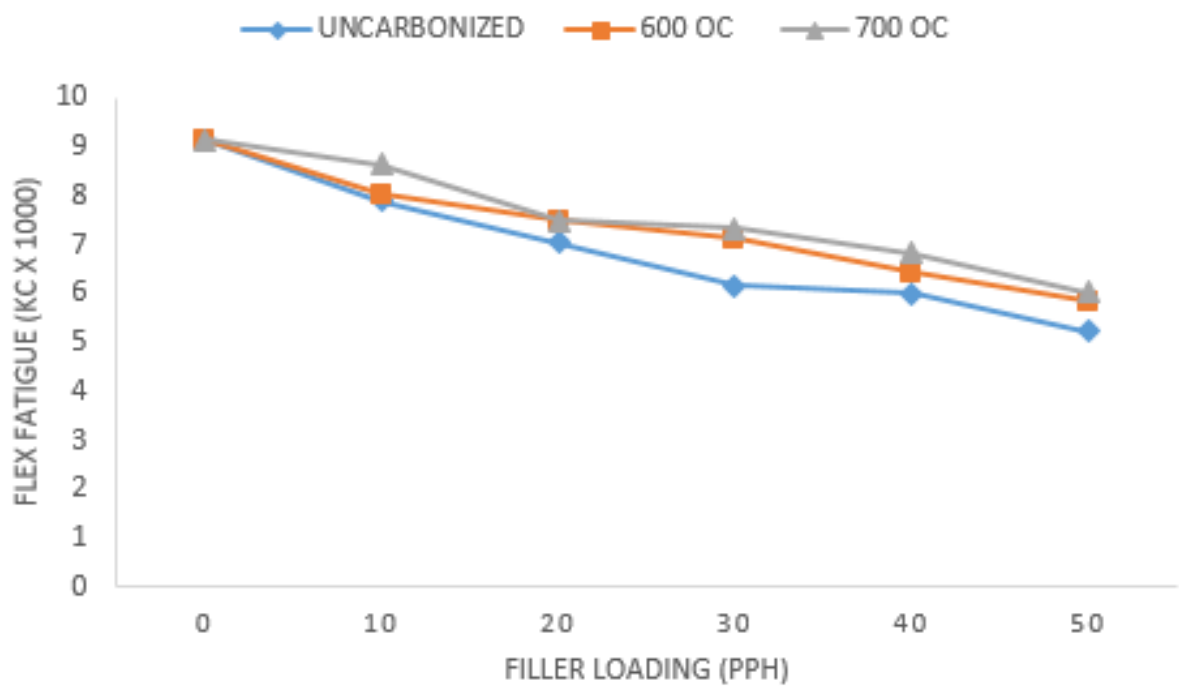

Figure 7. Flex Fatigue (\%) of the Wood-Flour Filled Vulcanisates 


\section{CONCLUSION}

Assessment of carbonised wood-flour on the mechanical properties of natural rubber was studied and the essence was to examine how the carbonised wood-flour may affect filler characteristics properties and hence the mechanical properties of natural rubber vulcanisates. The characterisation results revealed an increase in the $\mathrm{pH}$ (7.14 to 8.99) and loss on Ignition (76.32 to 82.04) of the carbonised wood-flour with increase in the carbonisation temperature. There was also a significant decrease in moisture content $(0.21$ to $0.15 \%)$ and bulk density $(0.63$ to $0.51 \mathrm{~g} / \mathrm{ml})$ with increasing temperature. Further results showed that carbonised wood-flour at $700{ }^{\circ} \mathrm{C}$ was more reinforcing for natural rubber compound than $600^{\circ} \mathrm{C}$ filler. The mechanical properties of the carbonised wood-flour filled vulcanisates were improved in the domain of tensile strength (6.08 to $10.38 \mathrm{MPa}$ and 7.19 to $12.65 \mathrm{MPa}$ ), tensile modulus (2.53 to $3.78 \mathrm{MPa}$ and 2.68 to $3.96 \mathrm{MPa}$ ) and hardness (48.25 to 60.55 Shore $A$ and 50.88 to 63.92 Shore $A$ ) as carbonisation temperature increases from $600{ }^{\circ} \mathrm{C}$ to $700{ }^{\circ} \mathrm{C}$ respectively. The results indicated that mechanical properties of the vulcanisates are greatly influenced by filler carbonisation temperature and are therefore significant factors in determining the application in rubber compounding. However, other properties investigated decreased with increased filler loading and carbonisation temperature and these were $\mathrm{EAB}$ (501.03 to $312.58 \%$ and 460.28 to $309.56 \%$ ), compression set (18.43 to $12.07 \%$ and 15.35 to $8.99 \%$ ), abrasion resistance (28.65 to $20.53 \%$ and 38.24 to $23.06 \%$ ) and flex fatigue (8.02 to $5.84 \%$ and 8.63 to $6.04 \%$ ) from $600{ }^{\circ} \mathrm{C}$ to $700{ }^{\circ} \mathrm{C}$ respectively.

\section{REFERENCES}

Ahmedna, M., Johnson, M., Ckarke, S. J., Marshal, W. E. and Rao, R. M. (1997). Potentials of Agricultural byproduct Based Activated Carbon for use in Raw Sugar Decolonization. Journal of Science and Food Agriculture, 75 , 117-124. https://doi.org/10.1002/(SICI)1097-0010(199709)75:1<117::AID-JSFA850>3.0.CO;2-M

Al-Ghamdi, A., Al-Hartomy, O., Al-Solamy, F., Dishovsky, N., Nickolov, R., Mihaylov, M., Malinova, P. and Ruskova, K. (2018). Preparation and Characterisation of Natural Rubber Composites Comprising Hybrid Fillers of Activated Carbon/in situ Synthesised Magnetite. Journal of Rubber Research, 21, 94-118. https://doi.org/10.1007/BF03449164

Ali, N. K. A. (2018). A new reinforcement material for rubber compounds (Sediment dust nanoparticles and white ceminte). 2018 1st International Scientific Conference of Engineering Sciences-3rd Scientific Conference of Engineering Science (ISCES). IEEE, 163-168. https:// doi.org/10.1109/ISCES.2018.8340547

Ansarifar, A. and Sheikh, S. H. (2018). Kaolin reinforcement of some rubbers with novel sulfur cure systems. Rubber Fibres Plastics International, 13, 44-50.

Asore, E. J. (2000). An Introduction to Rubber Technology, Benin City, Nigeria: Joseg book Limited.

Ebewele, R. O. (2000). Polymer Science and Technology. Florida, USA: CRC press. https://doi.org/10.1201/9781420057805

Eichhom, S. J., Baillie, C. A., Zafeiropoulos, N., Mwaikambo, L. Y., Ansell, M. P. and Dufresne, A. (2001). Current International Research into Cellulosic Fibres and Composites. Journal of Material Science, 36, 2107-3144. https://doi.org/10.1023/A:1017512029696

Heinz-Hermann, G. (2000). Natural Rubber, Ullmann's Encyclopedia of Industrial Chemistry. Weinheim: Wiley-VCH.

Hussain, A. K., Abdel, K. and Ibrahim, A. (2010). Effect of modifies linen fibre waste on physic-mechanical properties and Non-polar Rubber. Journal of Natural Science, 8.

Ishak, Z. A. M. and Baker, A. A. (1995). Natural Rubber Blends Properties. European Polymer Journal, 31, 259-269. https://doi.org/10.1016/0014-3057(94)00156-1

Jayaraj, S., Egodage, S. M. and Walpalage, S. (2017). Incoporation of nanoclay into filled latex to develop nanoclay filled dry rubber compounds. Journal of National Science Foundation of Sri Lanka, 45, 121-132. https://doi.org/10.4038/jnsfsr.v45i2.8178

Joseph, A. M., Madhusoodanan, K., Alex, R. and George, B. (2017). Incorporation of Devulcanised Rubber in Fresh Rubber Compounds: Impact of Filler Correction on Vulcanisate Properties. Progress in Rubber Plastics and Recycling Technology, 33, 281-302. https://doi.org/10.1177/147776061703300405

Kalia, S., Kaith, B. S. and Kar, I. (2009). Pre-Treatment of National Fibres and their Applications as Reinforcing Materials in Polymer Composites; A Review. Polymer Engineering and Science, 313-323.

Kamel, J. (2007). Nanotechnology and its Application in Lingocellulosic Composites; A Mini review. Express Polymer Letters, 1, 546-550. https:/ / doi.org/10.3144/expresspolymlett.2007.78

Krishnan, Y., Chandran, S., Usman, N., Smitha, T., Parameswaran, P. and Prema, K. (2015). Processability, mechanical and magnetic studies on natural rubber-ferrite composites. International Journal of Chemical Studies, 3 , $15-22$. 
Leelang, K. W. H. (1963). Microbiologic Degradation of Rubber. Jam Water Works Association, 53, 1523-1535. https://doi.org/10.1002/j.1551-8833.1963.tb01176.x

Linon, A., Steinbuchel, A., Sproer, C. and Kroppenstedt, R. M. (1999). Gordonia Polyisoprenivorans Sp Novel; A Rubber Degrading Actinomycete Isolated from Automobile Trye. International Journal of System Bacteriol, 49, 17851791. https://doi.org/10.1099/00207713-49-4-1785

Mansor, M. K. and Che Ali, R. (2016). Properties Evaluation of Micro-crystalline Cellulose and Starch as Bio-filler in Rubber Compounding. Advanced Materials Research, Trans Tech Publ, 593-597. https://doi.org/10.4028/www.scientific.net/AMR.1133.593

Mohanty, A. K., Misra, M., Aizal, L. T. and Kelly, S. 2001. Surface Modification of Natural fibres and performance of the resulting Bio composites. An overview of composites interfaces, 8 . https://doi.org/10.1163/156855401753255422

Moonchai, D., Moryadee, N. and Poosodsang, N. (2012). Comparative properties of natural rubber vulcanisates filled with defatted rice bran, clay and calcium carbonate. Maejo International Journal of Science and Technology, 6, 249.

Ogbebor, O. J., Okieimen, F. E., Ogbeifun, D. E. and Okwu, U. N. 2015. Preparation and properties of organokaolin natural rubber latex base vulcanisate. Adv Mater, 4, 75-79. https://doi.org/10.11648/j.am.20150404.11

Orts, W. J., Shey, J., Imam, S. H., Glenn, G. M., Guttman, M. E. and Revol, J. F. (2005). Application of Cellulose Micro-fibrils in Polymer Nanocomposites. Journal of Polymers and Environment, 13, 301-306. https://doi.org/10.1007/s10924-005-5514-3

Oyetunji, A., Bakare, I. O., Umunakwe, R. and Adeyemo, A. O. (2018). Properties Characterization of Vulcanized Natural Rubber Filled with Uncarbonized Particulate Cow Bone. FUOYE Journal of Engineering and Technology, 3.

Pandian, J. J. and Govindan, T. (2015). Comparative studies on the mechanical properties of natural rubber and natural rubber carbon black composites. IJETCSE, 13, 48-52.

Scandola, M., Frisoni, G. and Bariando, M. (2000). Chemically Modified Cellulosic Reinforcement. 219th ACS National Meetings, San Francisco, 26-30.

Sheikh, S. H. (2017). A study of the effects of kaolin, solid filler on the processing, mechanical, and dynamic properties of some industrial rubbers cured with novel sulphur cure system. $\mathrm{PhD}$, Loughborough University.

Sperling, L. H. (2006). Introduction to Physical Polymer Science. Wiley Inter-Science, A John Wiley and Sons, Incorporation.

Surya, I., Ismail, H. and Azura, A. 2015. The effect of alkanolamide loading on properties of carbon black-filled natural rubber (SMR-L), epoxidised natural rubber (ENR), and styrene-butadiene rubber (SBR) compounds. Polymer testing, 42, 208-214. https:// doi.org/10.1016/j.polymertesting.2014.12.009

Ugbaja, M. I., Ejiogu, K. I. and Dashe, J. D. (2016). The Impact of the Bark of Camel's Foot (Piliostigmathonningii) on the Physico-Mechanical Properties of Natural Rubber Vulcanizate. Journal of Energy, Environmental \& Chemical Engineering, 1, 19-23. https://doi.org/10.11648/j.jeece.20160101.13 